\title{
CLINICAL STUDIES OF THE BLOOD VOLUME. V. HYPERTHYROIDISM AND MYXEDEMA
}

\author{
By JOHN G. GIBSON, 2D, AND ALFRED W. HARRIS \\ (From the Department of Medicine, Harvard Medical School and the Medical Clinic of the \\ Peter Bent Brigham Hospital, Boston)
}

(Received for publication September 7, 1938)

In a study of the blood volume in normal human beings (1) a relationship between the total circulating blood volume and the basal metabolic rate was observed. In a group of 99 individuals the distribution of cases above and below the average total blood volume was similar to the distribution of basal metabolic rates above and below average normal values, and the decline in total blood volume with advancing age was parallel to the decline in basal metabolic rate. An increase in total blood volume, the degree of which was related to the severity of the condition, was found in patients with congestive heart failure (2) in which it may be assumed that the oxygen carrying mechanism was inefficient in meeting the tissue oxygen requirement. This observation suggested that the level of oxygen consumption might exert a considerable effect on the circulating blood volume, and prompted us to undertake a study of the blood volume in hyperthyroidism and myxedema in which the metabolism is severely disturbed.

Previous studies have indicated that hyperthyroidism is characterized by an abnormally high $(3,4,5)$ and myxedema by an abnormally low circulating blood volume $(6,7,8)$. Chang (4), using the $\mathrm{CO}$ method, found no direct relationship between the degree of increase in basal metabolic rate and increase in blood volume but observed decreases in blood volume with clinical recovery in all his cases. Goldbloom and Libin (5), using a dye method, found the increases above their normal values in hyperthyroidism great enough to lead them to believe that determination of blood volume was of value in the differential diagnosis of hyperthyroidism. Thompson (6) found the plasma volume about 30 per cent below normal in untreated cases of myxedema. On treatment, with the return of the basal metabolic rate to normal, the plasma volume rose to within normal limits.

\section{MATERIAL AND METHODS}

Twenty females and 5 males with clinically proven hyperthyroidism were studied. The basal metabolic rate was more than 15 per cent above normal in all cases. In 5 males and 10 females the changes in plasma and total blood volume were followed during the course of therapeusis, and determinations were made in all of these cases at intervals varying from 5 to 22 days after subtotal thyroidectomy was performed. In 2 males and 4 females blood volume was determined pre-operatively after the administration of Lugol's solution.

Single blood volume determinations were made in 5 females and 2 males with clinically proven myxedema. The basal metabolic rate was more than 15 per cent below normal in all cases. One man with pernicious anemia developed myxedema during a relapse, and another man developed myxedema some time after subtotal thyroidectomy.

Basal metabolic rates were determined by the standard technique of Benedict and Roth (9); plasma and total blood volume were determined by the direct method of Gibson and Evans (10); venous pressure was determined by the direct method of Evans (11) and circulation time by the decholin method of Winternitz, Deutsch, and Brüll (12).

\section{RESULTS}

Surface area rather than height was taken as the basis for prediction of normal plasma and total blood volume, inasmuch as the basal metabolic rates were based upon surface area. In almost every case the clinical history revealed the loss of some weight prior to admission to the hospital, and it is possible that the predicted volumes based upon surface area may represent values that were too high in some instances. The actual total blood volumes determined in these cases may well represent, therefore, greater percentage deviations from the normal volumes than indicated.

The course of the basal metabolism, plasma and total blood volume, hematocrit, venous pressure, and circulation time in 25 cases of hyperthyroidism and in 7 cases of myxedema is shown in Table $\mathrm{I}$. 
TABLE I

Absolute plasma, cell, and total blood volume; normal total blood volume predicted from surface area, venous pressure, and circulation time in 25 cases of hyperthyroidism and 7 cases of myxedema

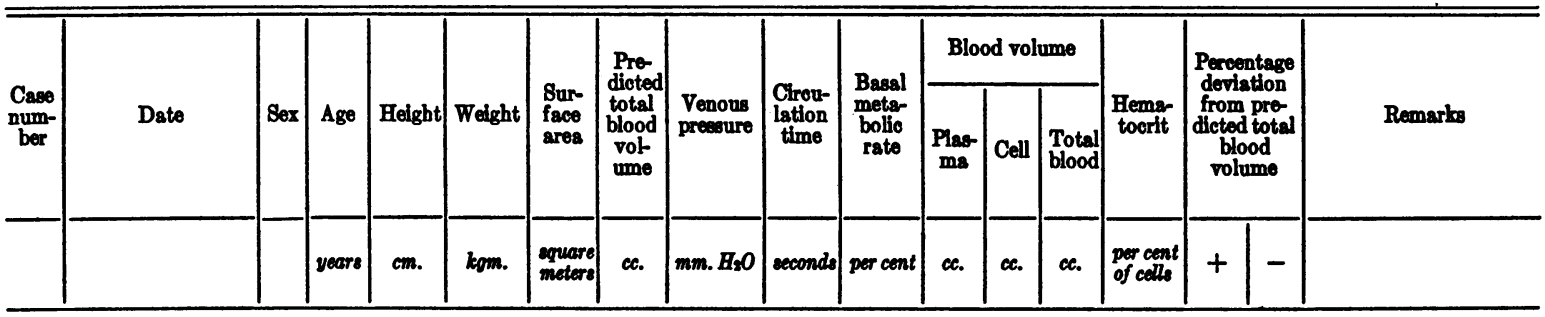

25 PATEMTS WTYH ETPERTHYBODISA

\begin{tabular}{|c|c|c|c|c|c|c|c|c|c|c|c|c|c|c|c|c|c|}
\hline $\begin{array}{l}9 \\
12 \\
18 \\
23 \mathrm{~A} \\
23 \mathrm{~B} \\
28 \mathrm{~A} \\
28 \mathrm{~B} \\
31 \mathrm{~A} \\
31 \mathrm{~B} \\
60 \mathrm{~A} \\
60 \mathrm{~B} \\
40 \\
64 \mathrm{~A} \\
84 \mathrm{~A} \\
84 \mathrm{~B} \\
85 \mathrm{~A} \\
85 \mathrm{~B} \\
179 \\
233 \mathrm{~A} \\
233 \mathrm{~B} \\
233 \mathrm{C} \\
282 \mathrm{~A} \\
232 \mathrm{~B} \\
232 \mathrm{C} \\
241 \mathrm{~A} \\
241 \mathrm{~B} \\
338 \mathrm{~A} \\
340 \\
344 \\
845 \mathrm{~A} \\
345 \mathrm{~B} \\
346 \mathrm{~A} \\
346 \mathrm{~B} \\
348 \mathrm{~A} \\
348 \mathrm{~B} \\
350 \mathrm{~A} \\
350 \mathrm{C} \\
351 \mathrm{~A} \\
351 \mathrm{~B} \\
352 \mathrm{~A} \\
352 \mathrm{~B} \\
356\end{array}$ & 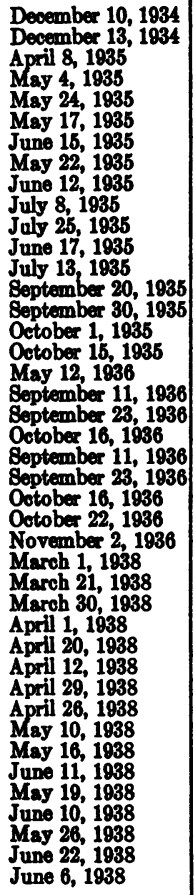 & $\begin{array}{l}\mathbf{M} \\
\mathbf{F} \\
\mathbf{F} \\
\mathbf{F} \\
\mathbf{F} \\
\mathbf{F}\end{array}$ & $\begin{array}{l}40 \\
23 \\
42 \\
41 \\
34 \\
22 \\
38 \\
\\
28 \\
48 \\
42 \\
28 \\
37 \\
36\end{array}$ & $\begin{array}{l}160.0 \\
165.6 \\
156.8 \\
152.5 \\
152.5 \\
167.5 \\
167.5 \\
164.0 \\
164.0 \\
163.8 \\
163.8 \\
158.8 \\
157.4 \\
156.4 \\
156.4 \\
171.5 \\
171.5 \\
162.6 \\
174.5 \\
174.5 \\
174.5 \\
152.5 \\
152.5 \\
152.5 \\
176.5 \\
176.5 \\
172.7 \\
168.3 \\
171.5 \\
162.5 \\
162.5 \\
158.8 \\
158.8 \\
149.5 \\
149.5 \\
176.0 \\
176.0 \\
148.8 \\
148.8 \\
175.0 \\
175.0 \\
160.0\end{array}$ & $\begin{array}{l}55.0 \\
66.0 \\
51.7 \\
56.0 \\
56.4 \\
54.5 \\
52.4 \\
43.2 \\
44.6 \\
70.0 \\
64.6 \\
48.4 \\
52.3 \\
62.4 \\
60.0 \\
50.6 \\
50.0 \\
52.0 \\
65.3 \\
65.5 \\
66.8 \\
47.6 \\
55.8 \\
54.1 \\
63.7 \\
68.3 \\
76.4 \\
74.4 \\
86.9 \\
60.8 \\
59.3 \\
57.0 \\
55.4 \\
49.8 \\
46.9 \\
84.2 \\
82.2 \\
59.6 \\
56.0 \\
68.6 \\
69.4 \\
58.6\end{array}$ & $\begin{array}{l}1.55 \\
1.71 \\
1.49 \\
1.50 \\
1.515 \\
1.60 \\
1.58 \\
1.40 \\
1.44 \\
1.75 \\
1.69 \\
1.47 \\
1.50 \\
1.61 \\
1.58 \\
1.58 \\
1.57 \\
1.53 \\
1.78 \\
1.79 \\
1.79 \\
1.41 \\
1.51 \\
1.49 \\
1.78 \\
1.81 \\
1.89 \\
1.81 \\
1.97 \\
1.63 \\
1.62 \\
1.57 \\
1.55 \\
1.42 \\
1.37 \\
1.99 \\
1.98 \\
1.53 \\
1.48 \\
1.82 \\
1.83 \\
1.59\end{array}$ & $\begin{array}{l}4025 \\
4175 \\
3850 \\
3900 \\
3925 \\
4100 \\
4075 \\
3450 \\
3725 \\
4175 \\
4175 \\
3800 \\
3900 \\
4100 \\
4075 \\
4075 \\
4050 \\
3950 \\
5250 \\
5275 \\
5300 \\
3525 \\
3925 \\
3875 \\
5250 \\
5350 \\
4175 \\
4175 \\
4175 \\
4125 \\
4100 \\
4025 \\
4000 \\
3650 \\
3425 \\
6000 \\
5975 \\
3950 \\
3825 \\
5400 \\
5450 \\
4075\end{array}$ & $\begin{array}{r}80 \\
80 \\
80 \\
75 \\
90 \\
70 \\
65 \\
55 \\
105 \\
60 \\
55 \\
100 \\
65 \\
60 \\
65 \\
65 \\
65 \\
30 \\
75 \\
45 \\
20 \\
90 \\
80 \\
100 \\
40 \\
40 \\
75\end{array}$ & $\begin{array}{l}8 \\
11 \\
10 \\
10 \\
10 \\
9 \\
10 \\
11 \\
11 \\
10 \\
11 \\
8 \\
12 \\
12 \\
12 \\
11 \\
12 \\
9 \\
14 \\
14 \\
18 \\
12 \\
12 \\
17 \\
16 \\
22 \\
19 \\
18 \\
14 \\
10 \\
8(9) \\
13 \\
13 \\
14 \\
15 \\
24 \\
16 \\
17 \\
12 \\
16 \\
12\end{array}$ & $\begin{array}{l}+27 \\
+55 \\
+51 \\
+61 \\
+3 \\
+47 \\
+6 \\
+70 \\
+7 \\
+46 \\
+16 \\
+66 \\
+58 \\
+35 \\
+31(8) \\
+30 \\
+11 \\
+20 \\
+24 \\
+14 \\
+3 \\
+38 \\
+14 \\
+19 \\
+17 \\
+4 \\
+23 \\
+46 \\
+30 \\
+48 \\
+28 \\
+47 \\
+1 \\
+47 \\
+28 \\
+49 \\
+2 \\
+60 \\
+26 \\
+53 \\
+6 \\
+46\end{array}$ & $\begin{array}{l}2380 \\
3105 \\
2350 \\
2335 \\
2270 \\
2740 \\
2680 \\
2480 \\
2250 \\
2665 \\
2240 \\
1900 \\
2470 \\
3090 \\
2535 \\
2270 \\
1990 \\
2265 \\
2600 \\
2980 \\
2900 \\
2075 \\
2150 \\
2180 \\
2955 \\
2530 \\
2600 \\
2900 \\
2810 \\
2350 \\
2000 \\
2180 \\
2220 \\
2180 \\
1900 \\
4330 \\
4100 \\
2440 \\
1720 \\
3250 \\
3000 \\
2150\end{array}$ & $\begin{array}{l}1970 \\
1665 \\
1650 \\
1575 \\
1200 \\
1610 \\
1345 \\
1900 \\
1580 \\
1765 \\
1540 \\
1760 \\
2160 \\
2000 \\
1675 \\
1600 \\
1330 \\
1365 \\
2220 \\
2380 \\
2225 \\
1435 \\
1320 \\
1135 \\
2495 \\
2000 \\
2160 \\
2040 \\
2060 \\
1650 \\
1530 \\
1580 \\
1440 \\
1900 \\
1280 \\
2800 \\
2380 \\
1610 \\
1470 \\
2690 \\
2170 \\
1580 \\
\end{array}$ & $\begin{array}{l}4350 \\
4770 \\
4000 \\
3910 \\
3470 \\
4350 \\
4025 \\
4380 \\
3840 \\
4430 \\
3780 \\
3660 \\
4630 \\
5090 \\
4210 \\
3870 \\
3320 \\
3630 \\
4820 \\
5360 \\
5125 \\
3510 \\
3470 \\
3315 \\
5450 \\
4530 \\
4760 \\
4940 \\
4870 \\
4000 \\
3530 \\
3760 \\
3660 \\
4080 \\
3180 \\
7130 \\
6480 \\
4050 \\
3190 \\
5940 \\
5170 \\
3730 \\
\end{array}$ & $\begin{array}{l}45.3 \\
36.1 \\
41.6 \\
40.7 \\
36.1 \\
37.4 \\
34.0 \\
42.4 \\
41.8 \\
40.5 \\
40.8 \\
38.2 \\
37.5 \\
39.3 \\
39.9 \\
41.5 \\
41.2 \\
39.8 \\
46.0 \\
44.4 \\
43.4 \\
40.7 \\
37.9 \\
34.3 \\
45.8 \\
44.3 \\
45.5 \\
41.1 \\
42.3 \\
41.2 \\
43.4 \\
41.9 \\
39.3 \\
46.5 \\
40.4 \\
39.3 \\
36.7 \\
39.6 \\
46.1 \\
45.3 \\
42.2 \\
42.3\end{array}$ & $\begin{array}{r}8.1 \\
14.3 \\
3.9 \\
0.3 \\
6.1 \\
27.0 \\
3.1 \\
6.1\end{array}$ & $\begin{array}{r}5.0 \\
17.9 \\
8.1 \\
8.2 \\
3.3 \\
0.4 \\
9.2 \\
11.5 \\
3.8 \\
15.3\end{array}$ & $\begin{array}{l}8 \text { days postoperatively } \\
10 \text { days postoperatively } \\
8 \text { days postoperatively } \\
9 \text { days postoperatively } \\
\text { Iodine administration } \\
7 \text { days postoperatively } \\
\text { Iodine administration } \\
22 \text { days postoperatively } \\
\text { Iodine administration } \\
21 \text { days postoperatively } \\
\text { Iodine administration }\end{array}$ \\
\hline
\end{tabular}

7 PATEANTB WTFH YTXODEMA

\begin{tabular}{|c|c|c|c|c|c|c|c|c|c|c|c|c|c|c|c|c|c|}
\hline $\begin{array}{l}10 \\
29 \\
234 \mathrm{~A} \\
234 \mathrm{~B} \\
239 \\
241 \mathrm{C} \\
271 \mathrm{D} \\
353 \mathrm{~A} \\
353 \mathrm{~B}\end{array}$ & $\begin{array}{l}\text { December 11, } 1934 \\
\text { May 18, 1935 } \\
\text { September 22, } 1936 \\
\text { Ootober 13, } 1936 \\
\text { Ootober 20, 1936 } \\
\text { December 11, } 1936 \\
\text { April 1, 1937 } \\
\text { May 26, 1938 } \\
\text { July 7, 1938 }\end{array}$ & $\begin{array}{l}\mathbf{F} \\
\mathbf{F} \\
\mathbf{F} \\
\mathbf{M} \\
\mathbf{M} \\
\mathbf{F}\end{array}$ & $\begin{array}{l}\mathbf{5 3} \\
\mathbf{6 2} \\
\mathbf{4 5} \\
42 \\
\mathbf{4 2} \\
\mathbf{3 9} \\
\mathbf{7 2} \\
\mathbf{5 9}\end{array}$ & $\begin{array}{l}165.5 \\
161.5 \\
172.5 \\
172.5 \\
158.8 \\
176.5 \\
177.5 \\
153.8 \\
153.8\end{array}$ & $\begin{array}{l}72.1 \\
63.6 \\
53.3 \\
54.3 \\
66.6 \\
76.0 \\
75.4 \\
69.4 \\
65.2 \\
65.7\end{array}$ & $\begin{array}{l}1.78 \\
1.66 \\
1.61 \\
1.63 \\
1.68 \\
1.91 \\
1.92 \\
1.66 \\
1.62\end{array}$ & $\begin{array}{l}4150 \\
4150 \\
4100 \\
4125 \\
4150 \\
5725 \\
5775 \\
4150 \\
4125\end{array}$ & $\begin{array}{r}80 \\
65 \\
95 \\
100 \\
60 \\
45 \\
90\end{array}$ & $\begin{array}{l}23 \\
45 \\
26 \\
20 \\
23 \\
35 \\
22 \\
22\end{array}$ & $\begin{array}{l}-15 \\
-17 \\
-43 \\
-20 \\
-18 \\
-21 \\
-23 \\
-33 \\
-12\end{array}$ & $\begin{array}{l}3070 \\
2030 \\
2490 \\
2485 \\
2120 \\
2680 \\
2730 \\
1860 \\
2450\end{array}$ & $\begin{array}{l}1170 \\
1530 \\
1210 \\
1235 \\
1400 \\
2020 \\
2240 \\
1290 \\
1410\end{array}$ & $\begin{array}{l}4170 \\
3560 \\
3700 \\
3720 \\
3520 \\
4700 \\
4970 \\
3150 \\
3860\end{array}$ & $\begin{array}{l}26.4 \\
43.0 \\
32.7 \\
33.2 \\
39.8 \\
43.0 \\
45.0 \\
40.8 \\
36.5\end{array}$ & 0.5 & $\begin{array}{r}14.2 \\
9.8 \\
9.8 \\
15.2 \\
17.9 \\
13.9 \\
24.1 \\
8.9\end{array}$ & $\begin{array}{l}\text { On thyroid medication } \\
\text { Post-total thyroideotomy } \\
\text { Pernicious anemis } \\
\text { On thyroid medication }\end{array}$ \\
\hline
\end{tabular}

In Figure 1 is shown the distribution of cases of hyperthyroidism and myxedema above and below normal total blood volume as predicted on the basis of surface area. It is evident that in comparison with the curve of distribution of total blood volumes in normals, the cases with hyperthyroidism form a group with the volumes definitely increased above normal, and that the cases with myxedema form a group with definitely subnormal volumes. Thus in the 25 cases of hyperthyroidism 17 'cases had a total blood volume which was within plus or minus 10 per cent of predicted normal value, 8 were above 10 per cent above normal, while none were less than 10 per cent below normal. In the group of patients with myxedema only one case had a volume in 


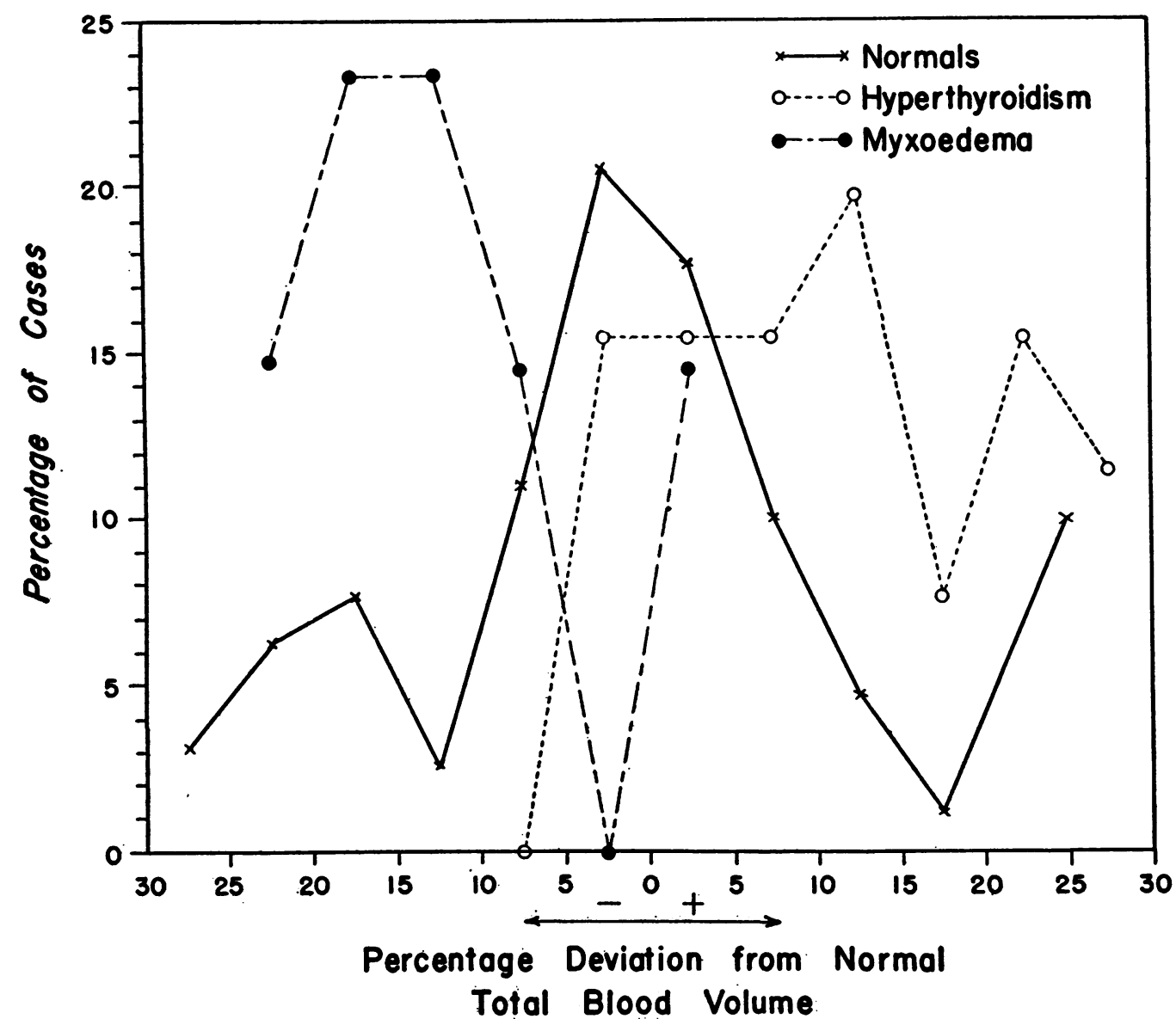

Fig. 1. The Distribution of the Percentage of Cases Above and Below Predicted Normal Total Blood Volume in 25 Cases of Hyperthyroidism and 7 Cases of Myxedema Compared to the Distribution of the Percentage of Cases Above and Below Average Normal Total Blood Volume in 99 Normal Humans

excess of predicted normal value, only 2 cases fell within limits of plus or minus 10 per cent of normal, and 5 cases had volumes more than 10 per cent below normal.

The percentage deviation from predicted normal total blood volume based on surface area is shown in relation to basal metabolic rate in Figure 2. A direct relationship between deviation from predicted normal total blood volume and the levels of basal metabolic rate was observed. Prior to treatment, the circulation time was below normal in all except one case of hyperthyroidism and above normal in all the cases of myxedema. Venous pressures were within the limits of normality of the method employed in all cases in which the determination was made. The direct relationship between the speed of blood flow and basal metabolic rate reported by Blumgart, Gargill, and Gilligan (13) in hyperthyroidism was confirmed.

No significant relationship between the percentage deviation from predicted normal volume based on surface area and circulation time or venous pressure was observed.

The change in the absolute total blood volume in 5 males and 10 females in relation to change in basal metabolic rate occurring during the course of therapy is shown in Figure 3. In all cases the basal metabolic rate was lower after operation, and in all except 1 case the total blood volume was less postoperatively than it was at the initial determination. Reduction in total blood volume postoperatively ranged from 540 to $770 \mathrm{cc}$., or an average of $650 \mathrm{cc}$. in males, and from 100 to 900 


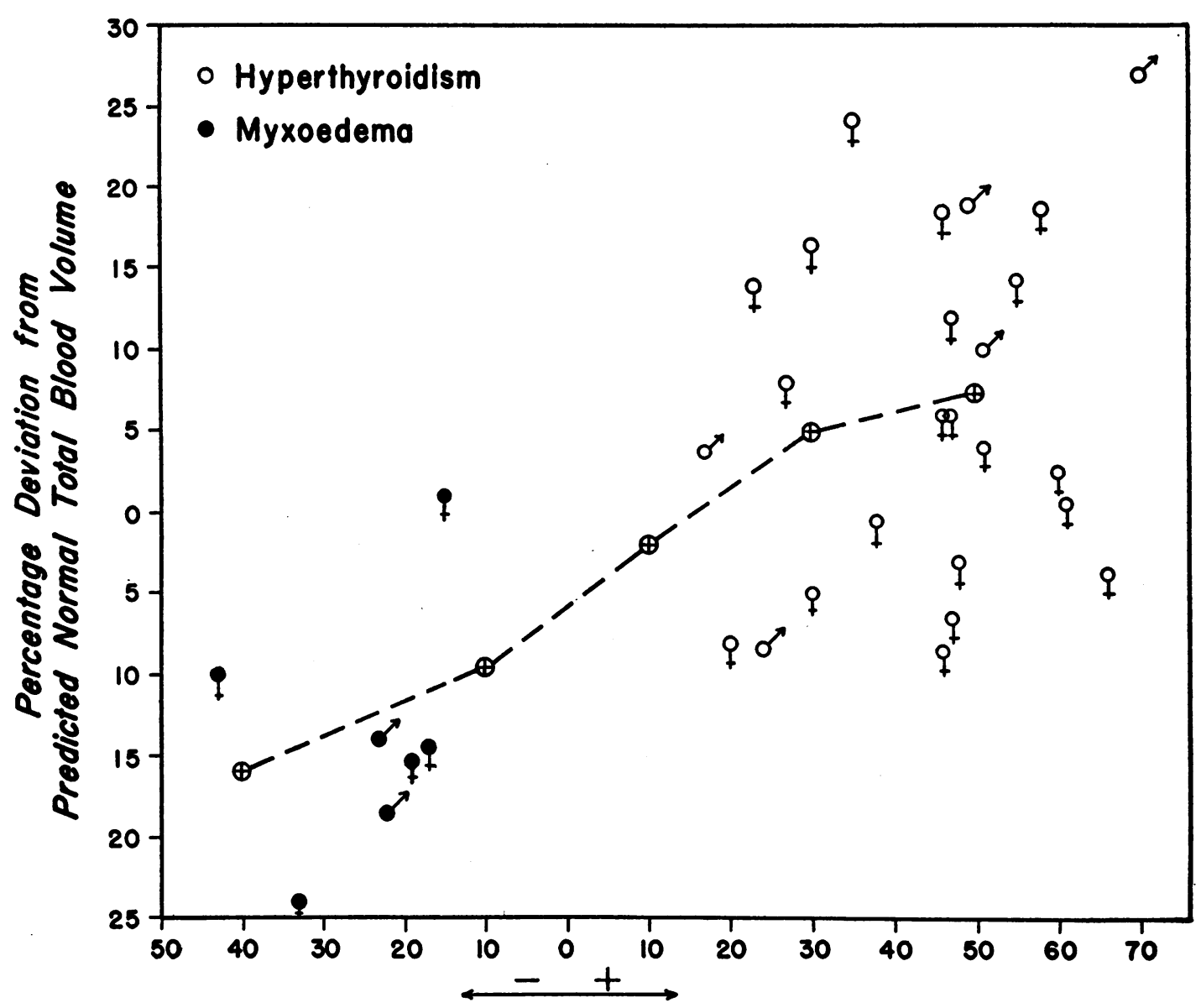

\section{Basal Metabolic Rate}

Fig. 2. Percentage Deviation from Normal Total Blood Volume as Predicted on the Basis of Surface Area in 25 Cases of Hyperthyroidism and 7 Cases of Myxedema in Relation to Basal Metabolic Rate

cc. or an average of 500 cc. in females. In 1 male and 3 females the total blood volume decreased during the course of iodine administration. The total blood volume determined postoperatively was higher than that following iodine administration in 1 male and lower in 1 male and 1 female.

In 2 cases of myxedema, following the increase in basal metabolic rate resulting from thyroid therapy the total blood volume was unchanged in one and definitely increased in the other.

\section{DISCUSSION}

Our findings are somewhat at variance with those reported in the literature. Chang (4), using the $\mathrm{CO}$ method, found an average increase over his accepted normal value for total blood volume of about 17 per cent in 21 cases of hyperthyroidism. Goldbloom and Libin (5), employing a modification of the dye method of Seyderhelm and Lampe, found the total blood volume increased by 50 per cent over normal in 9 cases with hyperthyroidism. The average increase over normal in our series of 25 cases was only 6 per cent. Thompson (6) found the total blood volume to be about 25 per cent below normal in 9 cases of myxedema. The average in our group of 7 myxedematous patients was 15 per cent below normal.

In our opinion certain errors inherent in the earlier dye techniques, principally those arising from differences in the time required for the dye to become completely mixed in the blood stream 


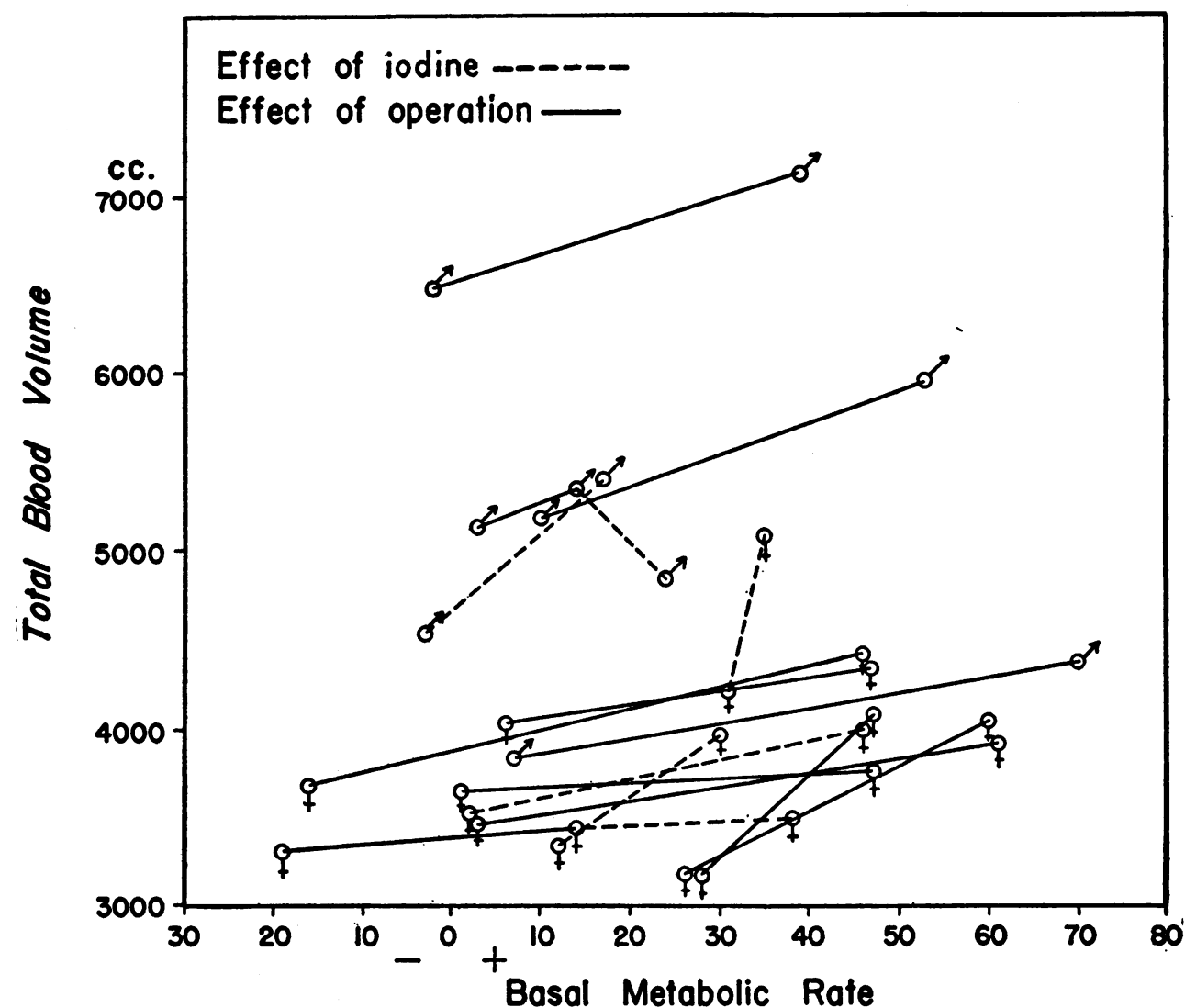

Fig. 3. Decrease in Total Blood Volume in Hyperthyroidism with Decrease in Basal Metabolic Rate Following Therapy

Dotted lines indicate the change taking place under treatment with Lugol's solution only; solid lines indicate the change following subtotal thyroidectomy.

in individuals with extremely rapid or slow circulation times (10), may be responsible for the discrepancies in results obtained by the above authors and those obtained in this study. The higher values found by Chang (4) may be attributed to the fact that the $\mathrm{CO}$ method probably measures myohemoglobin in addition to circulating oxyhemoglobin.

In both groups of patients in this series there were considerable variations in individual cases from the trend exhibited by the group as a whole, and therefore the determination of the blood volume has little, if any, practical value in the differential diagnosis of either hyperthyroidism or myxedema. Several factors account for these variations. In the determination of basal metabolic rates, oxygen consumption can be determined only within rather wide limits. It is common knowledge that errors are more prone to be in the direction of too high rather than too low rates, and that the technical difficulties of accurate determinations increase with the severity of the clinical condition of the patient. In addition, as stated above, standards of normality are at best arbitrary values when applied to individuals and while the conclusions drawn from a sufficiently large group of cases may be valid, the findings in an individual case may not be in keeping with average trends.

Further evidence that in hyperthyroidism total blood volume determined at the height of the rise in metabolism is increased over the level of the individual in a normal metabolic state may be adduced from the fact that in all cases successful treatment of the disorder, as evidenced by a reduction in the metabolic rate, was accompanied by a prompt and considerable fall in the total blood volume. This reduction was greater than could 
be accounted for by rest, or by the minor hemorrhage incident to operation. The reduction occurring coincident with the lowering of the metabolic rate was shared equally by plasma and red cell volume. The percentage of reduction in red cell volume occurring after therapy bears a linear relationship to the fall in metabolic rate as is shown in Figure 4.

In our opinion the total blood volume is definitely related to the oxygen requirement as expressed by the basal metabolic determination. Other than an increase above normal requirements in the total number of circulating red cells in hyperthyroidism and a decrease in myxedema, no explanation of the mechanism of the volume change characteristic of these diseases has come to light.

None of these cases of hyperthyroidism had any evidence of valvular diseases or hypertensive heart disease nor did they exhibit any of the physical signs of congestive heart failure. The greatest increase in total blood volume above normal in this series was 28 per cent and the average about 6 per cent. In frank congestive failure the average increase in total blood volume above normal is 22 per cent (2). It would appear that even in the presence of an increased cardiac burden, the mechanical disadvantage imposed by the degree of hypervolemia experienced by these thyrotoxic patients was not enough to

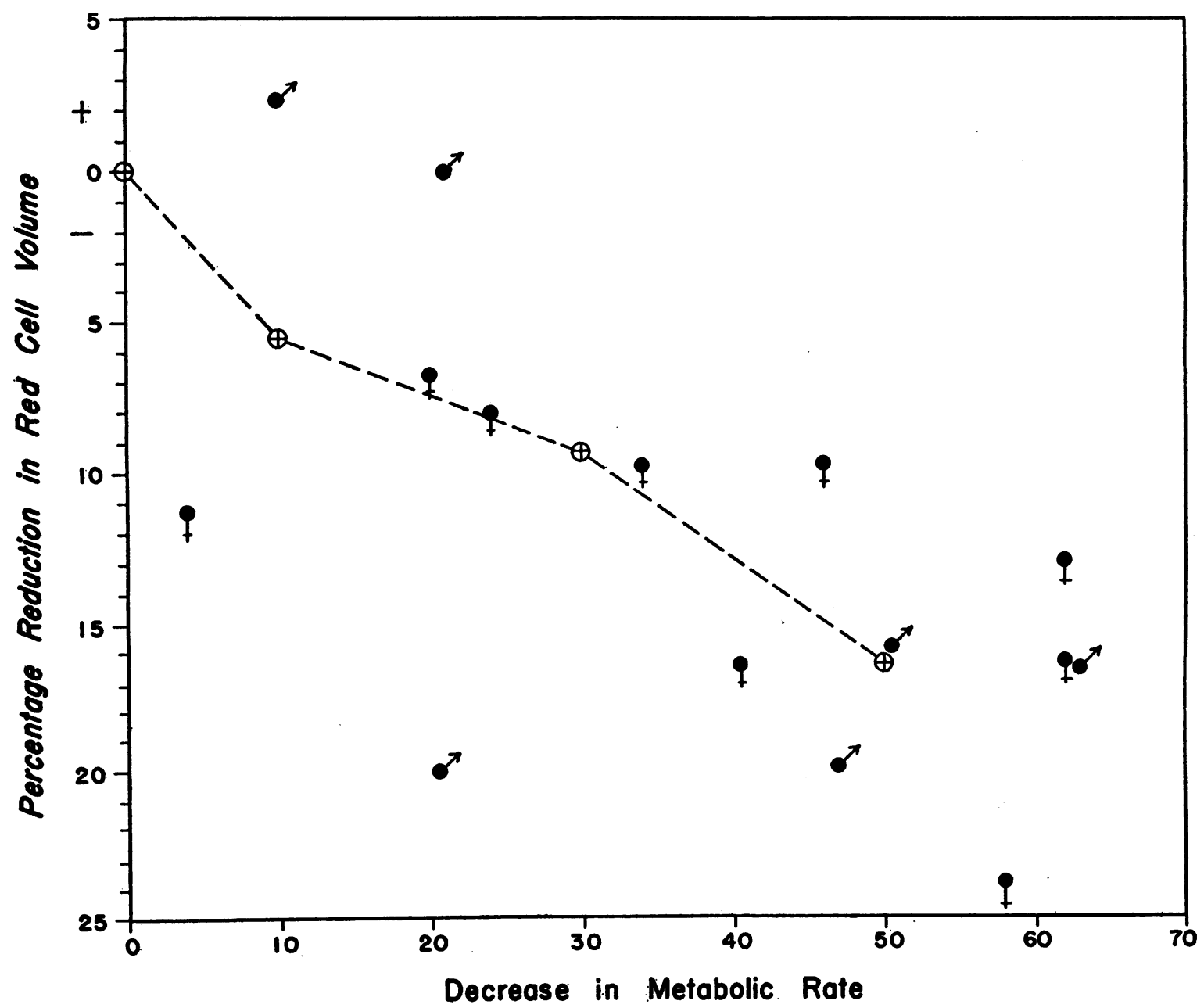

Fig. 4. Percentage Reduction from Initial Circulating Red Cell. Volume Occurring after Therapy in Hyperthyroidism in Relation to the absolute Decrease in Basal Metabolic Rate 
precipitate congestive heart failure. However, in the absence of known specific pathological changes in the thyroid heart $(14,15)$, the hypervolemia brought about by the increased oxygen requirement of this diseased state may offer some explanation as to the mechanism of congestive heart failure in cases of hyperthyroidism.

\section{CONCLUSIONS}

(1) In 25 cases of hyperthyroidism the total blood volume was increased above normal on an average of 5.45 per cent; and 15.5 per cent below normal in 7 cases of myxedema.

(2) The deviation from normal in the untreated hyperthyroid state bears a linear relationship to the oxygen requirement as measured by the determination of the basal metabolic rate.

(3) In hyperthyroidism successful treatment is accompanied by a decrease in red cell and total blood volume commensurate with the lowering in basal metabolic rate.

We wish to express our thanks to Drs. H. L. Blumgart and M. D. Altschule of the Beth Israel Hospital, Boston, for permission to utilize clinical material. Miss Evelyn Berstein gave valuable technical assistance.

\section{BIBLIOGRAPHY}

1. Gibson, J. G., 2D, and Evans, Wm. A., Jr., Clinical studies of the blood volume. II. The relation of plasma and total blood volume to venous pressure, blood velocity rate, physical measurements, age and sex in ninety normal humans. J. Clin. Invest., 1937, 16, 317.

2. Gibson, J. G., 2D, and Evans, Wm. A., Jr., Clinical studies of the blood volume. III. Changes in blood volume, venous pressure and blood velocity rate in chronic congestive heart failure. J. Clin. Invest., 1937, 16, 851.
3. Rowntree, L. G., and Brown, G. E., The Volume of the Blood and Plasma in Health and Disease, W. B. Saunders Co., Philadelphia, 1929.

4. Chang, $H$., The blood volume in hyperthyroidism. J. Clin. Invest., 1931, 10, 475.

5. Goldbloom, A. A., and Libin, I., Clinical studies in circulatory adjustments. I. Clinical evaluation of studies of circulating blood volume. Arch. Int. Med., 1935, 55, 484.

6. Thompson, W. O., Studies in blood volume. I. The blood volume in myxedema with a comparison of plasma volume changes in myxedema and cardiac edema. J. Clin. Invest., 1926, 2, 477.

7. Blumgart, H. L., Gargill, S. L., and Gilligan, D. R., Studies on velocity of blood flow. XIV. The circulation in myxedema with a comparison of the velocity of blood flow in myxedema and thyrotoxicosis. J. Clin. Invest., 1931, 9, 91.

8. Holböll, S. A., Utber die Grösse der blutmenge bei patienten mit myxödem. Studien der blutmenge. Acta med. Scandinav., 1930, 73, 538.

9. Roth, P., Modifications of apparatus and improved technique adaptable to the Benedict type of respiration apparatus. Boston $M$. and S. J., 1922, 186, 457.

10. Gibson, J. G., 2D, and Evans, Wm. A., Jr., Clinical studies of the blood volume. I. Clinical application of a method employing the azo dye "Evans Blue" and the spectrophotometer. J. Clin. Invest., 1937, $16,301$.

11. Evans, Wm. A., Jr., Venous pressure. New England J. Med., 1932, 207, 1934.

12. Winternitz, M., Deutsch, J., and Brüll, Z., Eine Klinisch brauchbare Bestimmungsmethode der Blutumlaufszeit mittels Decholininjektion. Med. Klin., 1931, 27, 986.

13. Blumgart, H. L., Gargill, S. L., and Gilligan, D. R., Studies on velocity of blood flow. XIII. The circulatory response to thyrotoxicosis. J. Clin. Invest., 1930, 9, 69.

14. Rake, G., and McEachern, D., A study of the heart in hyperthyroidism. Am. Heart J., 1932, 8, 19.

15. Weller, C. V., Wanstrom, R. C., Gordon, H., and Bugher, J. C., Cardiac histopathology in thyroid disease. Am. Heart J., 1932, 8, 8. 